Intermedia International e-Journal, Spring -June - 2017 4(6)

Intermedia

International e-journal

ISSN: $2149-3669$

\title{
HOW TURKISH PR PROFESSIONALS AND STUDENTS USE DIGITAL RESOURCES
}

\author{
Asistant Professor, Erkan SAKA ${ }^{1}$ \\ Istanbul Bilgi University, Faculty of Communication, \\ Communication Design and Management Department, \\ İstanbul \\ Phd., Barika GÖNCÜ ${ }^{2}$ \\ Istanbul Bilgi University, Faculty of Communication, \\ Communication Design and Management Department, \\ İstanbul
}

\begin{abstract}
This study aims to address how Turkish industry practitioners use digital resources and how would-be PR practitioners learn to use the latter. In this respect, the main emphasis on digital communications will mostly be focused on social networking sites (Twitter in particular) and user generated content sites (Ekşisözlük in particular). The aim is to map out which sources emerge to determine reasons behind particular choices of digital sources, to focus on the evaluation processes of the gathered information and finally to elaborate the end results of these processes. The results of the research confirm that public relations professionals in Turkey are aware of the potential offered by digital communication and embraced the changes resulting from the digital turn in public relations.
\end{abstract}

Key Words: social networking, user generated content, public relations, online credibility, online verification.

Özet: Bu çalışma, Türkiye'deki halkla ilişkiler sektörü profesyonellerinin dijital kaynaklardan nasıl yararlandıklarını ve halkla ilişkiler profesyoneli adaylarının bu kaynakları kullanmayı nasıl öğrendiklerini ortaya koymayı amaçlamaktadır. Bu bağlamda dijital iletişimin ana vurgusu özellikle Twitter olmak üzere sosyal paylaşım platformları ve özellikle Ekşisözlük olmak üzere kullanıcı tarafından oluşturulmuş içerik platformlarıdır. Çalışmanın hedefi, profesyoneller ve öğrenciler tarafından tercih edilen dijital kaynakların, bu tercihlerin ardındaki nedenlerin ve erişilen bilgilerin değerlendirilme süreçlerinin fotoğrafını çekerek bu süreçlerin sonunda ortaya çıkan bilgileri yorumlamaktır. Çalışma sonuçları, Türkiye'deki halkla ilişkiler profesyonellerinin dijital iletişimin potansiyelinin farkında olduklarını ve halkla ilişkilerdeki dijital dönüşümü sahiplendiklerini göstermektedir.

Anahtar kelimeler: sosyal ağlar, kullanıcı tarafından oluşturulmuş içerik, halkla ilişkiler, çevrimiçi itibar, çevrmiçi doğrulama.

\footnotetext{
1 erkan.saka@bilgi.edu.tr

${ }^{2}$ barika.goncu@bilgi.edu.tr
} 


\section{Introduction}

Digital communications entered the phase of so-called Web 2.0 (O'Reilly, 2007) in which "participatory culture" becomes a norm (Jenkins, 2006). Here long held expert paradigms are under threat and every field of expertise is going through adaptive transformations. September 11, 2001 attacks triggered a wave of citizen media usage what was never seen before. It is a turning point in the rise of participatory culture in which citizens are directly involved in public debate through use of media. Blogging had gone through golden age at the turn of the 21st century and it was followed by social networks in an even more rapid pace. One of the early threatened field of expertise is journalism. Citizens were actively involved in news making in Iranian elections in 2009 (Grossman, 2009), in Arab Spring (Henriksson, 2011) and Occupy movements through using social media networks. As Morejon (2012) notes some of the most popular news were first created or massively disseminated in particular social networks such as Uprising in Egypt (Facebook), plane downed in Hudson River (Twitter), announcement of Royal wedding in UK (Twitter), murdered protesters in Bahrain (YouTube), Whitney Houston's death (Twitter), raid at the house where Usame bin Laden was hiding (Twitter).

Credibility of information that is passed through digital communication tools has quickly become one of the critical issues in the new media environment. More work has focused on journalism studies and the authors believe some of the discussions happening in journalism field can be extended to other fields, including public relations. Boston Marathon explosions in 2013 is just one of the major cases in which information verification and credibility issues once again became central. Users in Reddit and 4Chan were quick to do their own research but they ended up pointing out wrong persons as the guilty parties (Fitzpatrick, 2013). However, even in that case as Ulanoff (2013) stated Reddit was quick to reverse the wrongdoing in individual and institutional level. Reddit CEO Erik Martin apologized and promised to be more careful in similar instances (Laird, 2013). However, the real damage was done by CNN's hasty mistaken reporting which would be disseminated widely through Facebook and Twitter (Laird, 2013). Reddit corrected itself but CNN, Associated Press and the tabloid New York Post, all traditional channels, made graver mistakes in circulating wrong information (Groll, 2013). Still, digital communications remain to be scapegoats in our own everyday encounters with officials or experts.

In yet another dimension, user generated content triggered epistemological resolutions. Robinson and DeShano (2011, p. 975) state that "knowledge" does not have to be informed merely by institutionally approved facts, but can also derive from perspectives, opinions, rumor and other kinds of information products now being circulated as 'truth' about the local city. This was always the case but with massive citizen output this has become a more central dimension. Knowledge about a person or an event is not necessarily to be factual but socially constructed. Here, reliance on user generated content makes less epistemological uneasiness. AndénPapadopoulos and Pantti (2013)'s emphasis on the importance of craft of storytelling during crisis reporting could be extended to construction of public relations knowledge. Similarly what Zelizer (1993) claims about journalists as interpretive communities might even be more valid for public relations circles The contribution of the study to Public Relations profession is to demonstrate PR practitioners are engaged in a sort of interpretative community based on digital sources. In the meantime, Lewis, Williams and Franklin (2008) demonstrate that even the British quality journalism depends on public relations agents' outputs. This study in return shows at least PR students and professionals rely on popular user generated content to produce their own briefs.

\section{New media in public relations}

Social media spaces and tools, as well as providing platforms to convey messages and to interact with stakeholders, also serve as information sources for the practice of public relations. Following the emergence of the World Wide Web and the related tools and platforms in 1990s, there is now a consensus that public relations professionals are increasingly integrating social media and new media tools in their practices (Avery, Lariscy and Sweetser, 2010). 
Today, it is confirmed that public relations professionals, like their journalist 'cousins', make use of digital media and sources "to collect and curate information, create content, follow up with questions, and continue conversations" (Chimbel et al., 2014, p. 41). Recent research tells us that public relations is making use of the advantages of social media both as a tool to communicate organizational messages and to develop stakeholder relations (Verhoeven et al., 2012; Wright and Hinson, 2010). Within this context, social media tools and platforms are enabling public relations practitioners to directly communicate with their stakeholders (Wright and Hinson, 2013); to develop dialogue and relationships (Kelleher, 2009); to increase the visibility of the organizations and brands they represent (Yang and Kent, 2014); and to influence opinions (Men and Tsai, 2013).

Duhé's (2015) review of the prevailing themes in new media research published in public relations journals over the last 34 years provides a comprehensive picture of how the practice of public relations has been impacted by and has reacted to the digital revolution. As demonstrated by Duhé's (2015) overview, the research on new media in public relations has focused on the following major themes: how public relations can use the new channels of communication; how the developments in digital tools and platforms has impacted the various working areas of public relations; and the genuine/specific nature of digital communication.

Received with significant excitement, the potential of social media for public relations has been described as a "revolution" (Breakenridge, 2008; Hazelton, Harrison-Rexrode, and Kennan, 2007; Solis and Breakenridge, 2009). On the other hand, whether this potential is used in line with dialogic or excellence principles of public relations, remains an issue of debate (Robson and James, 2013).

Nearly two decades following the emergence of digital communication tools and platforms, the 2015 results of the European Communication Monitor (ECM) (Zerfass et al., 2015) reveal that coping with the digital evolution and the social web is still cited as the second most important challenge for communication management until 2018. This is undoubtedly due to the continuous and rapid evolution of digital platforms and technologies, as well as the hesitation of public relations professionals in the adoption of new technologies (Porter et al., 2009, p. 251). Furthermore, again according to the results of the ECM, when it comes to engaging stakeholders through organizational listening, social media communication is less preferred than face to face communication. While 86.7 $\%$ of Turkish public relations practitioners participating in ECM have reported that they regularly monitor traditional media for organizational listening, the ratio of Turkish practitioners who carry on regular social media monitoring for organizational listening is only $63.3 \%$. Nevertheless, the overall results reveal that "listening minded" communication departments are reportedly more advanced (77.4\%) in regular social media monitoring than other communication departments (66.2\%).

\section{Turkish public relations practitioners and the digital}

Research specifically on how advances in digital communication and in social media tools and platforms have impacted the practice of public relations in Turkey, or how and why Turkish public relations practitioners make use of these tools and platforms is rather scarce. Exceptions include Öztürk and Ayman's (2007) study on the usage of corporate web sites for public relations purposes; Onat's (2010) study examining the social media presence of Turkish environmental NGOs from a public relations perspective; Temizel, Sarıkaya and Bayram's (2010) article on how Turkish companies listed in the İstanbul Stock Exchange use their web sites to manage investor relations; a study by Canpolat (2012) to describe the different services provided by PR and advertising agencies through information derived from their corporate web sites; Tekvar's (2012) PhD dissertation on how new media is transforming the conceptualization and practice of public relations in different organizations (including PR agencies); Öztürk and Yılmaz's (2013) study on how the Turkish PR and advertising agencies use their corporate 
web pages; and Özel and Sert's (2014) article examining the corporate blogs of the top-500 companies in Turkey from a digital public relations perspective.

Emphasizing the increasing use of digital communication tools and several social media platforms, and the need for research on the adoption of social media by the public relations professionals; Alikilic and Atabek (2011)'s examination of the social media adoption of PR professionals in Turkey and how they employed digital tools both internally and externally, deserves a special mention. Their findings reveal that there is a high awareness among Turkish PR professionals about the existing and future potential of social media tools for public relations, and they use them in communicating with internal and external audiences. Also according to the findings, public relations professional in Turkey consecutively list social networks, corporate web sites, and personal digital applications as the most important social media to impact the future of public relations. Alikilic and Atabek (2011, p. 59-62) have also found that Turkish public relations practitioners demonstrated a good understanding of public relations functions, matching each function with appropriate social media tools; the most commonly used tools and platforms currently used being e-mails, social networks, and corporate web sites.

The public relations practitioners in Turkey, as their counterparts in other parts of the world, were not very quick in adapting to social media tools and platforms, and in incorporating the potential of these into their services. Again parallel to international examples, the delay of Turkish public relations practitioners in understanding the full dimensions of the digital transformation, and how this transformation was impacting the profession, led to the emergence of a significant number of "digital agencies" or "social media agencies" (ilhan, 2014). The same hesitation to adapt to digital technologies is also depicted in Tekvar's (2012) findings on the perception of the digital transformation by the Turkish public relations agencies, whose corporate digital accounts then were very few, and not very active and efficient. Furthermore, the small number of public relations agency digital accounts had a very low interaction, being used mainly for one-way communication. Additionally, interviewees from PR agencies said they preferred face-to-face communication rather than communicating online, and some of them did not even prefer to have personal accounts in social networking sites (Tekvar, 2012, p. 323330).

Confirmed also by international literature exploring the use of social media by public relations practitioners (Robson and James, 2013), the majority of Turkish public relations practitioners were not well prepared to tackle both the technical requirements of digital communication technologies and embrace the genuine dynamics of the social media space. The concerns of organizations and brands about transparency issues and organizational reservations on committing time and resources further delayed the digitalization of public relations practices. As noted by Illhan (2014), following the Gezi Park Protests of 2013 in Turkey ${ }^{3}$, management of perceptions on a variety of issues increasingly started to take place in digital platforms, and the pulse of social media began to play a significant role in determining the agenda of the conventional media. Furthermore, the increasing reflection of organizational crises in digital platforms forced organizations to take steps to manage their corporate digital accounts in a more sophisticated manner and to monitor social media more regularly. In this sense, the repercussions of the Gezi Park Protests were also observed in the world of public relations practitioners, where individual practitioners' and public relations agencies' use of social media platforms increased, and almost

\footnotetext{
${ }^{3}$ Gezi Park Protests: A wave of demonstrations and civil unrest in Turkey, which began on May 2013. The initial protest was against the urban development plan for Istanbul's Taksim Gezi Park. The protests then spread across Turkey, voicing a wide range of concerns at the core of which were issues of freedom of the press, of expression, assembly, and the government's encroachment on Turkey's secularism. (https://en.wikipedia.org/wiki/Gezi_Park_protests)
} 
all the leading public relations agencies started creating digital communication departments in an effort to integrate social media communication with the overall strategic communication services they offered.

Examples of such initiatives among leading Turkish public relations agencies, which are all members of the industry association IDA (Communication Consultancies Association of Turkey) include listing digital PR among agency competencies (Grup 7 PR, Bersay PR, MPR PR); hosting blogs on agency web sites (Tribeca PR, Grup 7 PR, Unite PR, Effect PR, Denove PR); creating affiliations with international digital communication agencies (Artı PR); preferring to communicate the agency credentials on platforms like Facebook and Twitter (Zarakol PR); and linking their websites to agency social media accounts on platforms like Linkedin, Facebook, Twitter, Instagram, and Google +.

\section{Focused research}

\section{1- Methodology}

The authors aimed to assess the current use of digital communication tools and platforms by the public relations practitioners in Turkey and also the graduate level public relations students. The public relations practitioners were interviewed, and the students participated in a focus group. While the public relations practitioners interviewed are actively-working top level consultants, some of the students participating in the focus group are already working in public relations related jobs, and some of them are planning to do so.

\section{2- Research questions}

10 public relations agency founding presidents were contacted and were asked to answer the following questions:

- Which digital tools/platforms do you use for which specific working area of public relations, and why do you choose those particular sources?

- $\quad$ In what way are digital tools/platforms significant for your business?

- $\quad$ How do you assess the credibility of digital tools/platforms/sources that you use?

- What, according to you, are the most widely used digital tools /platforms/sources by PR practitioners in Turkey? Which of these are currently on the rise?

In the same manner, 25 PR graduate students provided information and insight in focus group discussions on their use of digital information sources. Students were also asked to collect data in hypothetical situations like in a breaking news case, or about a future event or of collecting data about a person of less nationwide fame. All 37 active graduate students in a public relations graduate program were invited for interviews and focus groups and 25 of them were available to attend. Those who could not attend did send online responses to some of our inquiries. Among the participants, 13 were female and 21 of them had a job at the time of our research.

\subsection{Data Collection}

The questions were sent via-electronic mail to public relations consultants, following their verbal acceptance to participate in the research. Following the receipt of questions, the consultants were visited in their offices for oneon-one interviews. The interviews lasted an average of 45 minutes. All the interviews were recorded by Samsung Note 5 Smart Phone device and then transcribed. Additional written notes were also taken to support the analysis.

The students were invited to participate through a Facebook group for the department announcements and face to face in a mandatory graduate course. Electronic emails were sent to those who could not attend but intended to participate. Three focus groups took place in a designated room in the campus premises. There were 
follow up interviews with 5 students who attended focus groups in lecturer's office. All the focus group discussions and interviews were recorded by Samsung Note 3 Smart Phone device and then transcribed. 7 more interviews via emails from the students who could attend face to face discussions were also added for analyses.

\subsection{Recruitment of Participants}

Regarding the choice of 10 top level public relations consultants, relevancy was the primary concern of the authors. Since the authors' previous professional and academic networks enabled them with numerous relevant contacts, accessibility was not an issue. As contended by Rubin and Rubin (1995), the most important criterion for participant recruitment is that an interviewee has to have knowledge about the area of study of the research. In recruiting the public relations consultants, this criterion was taken into account. Both the agencies they represent and their individual assets demonstrate that the choice of these 10 communicators is relevant for the purposes of this research.

The public relations consultants contacted represent the leading agencies in the public relations consultancy industry in Turkey, with an average consultancy expertise of 10 to 15 years, and a solid experience on providing public relations consultancy services to top 500 national and international companies in Turkey. The client portfolios of IDA member PR agencies demonstrate that these agencies provide services to the Turkish operations of the majority of global companies in Turkey, as well as the majority of leading Turkish corporations (IDA, 2016). These consultants also represent public relations agencies that provide a full range of services, enabling them to provide insights on the use of digital communication in various working areas of public relations.

The credibility of IDA member PR agencies is further demonstrated by the increasing number of client organizations (such as the Central Bank of Turkey and Turkish Telecom) who are selecting their public relations agencies from among IDA members; and who are including the possession of CMS certification among prerequisites for participating in pitches (Turhan, 2014).

The participants of this research are the founders and presidents of 10 leading public relations agencies that have sustained their existence in the Turkish public relations industry for a considerable time. Considering the relatively young nature of the industry in Turkey, these agencies have an average history of 20 years, which means their founders have all witnessed the emergence and the development of the digital communication tools and platforms, at the same time facing the digital challenge. Prior to founding their agencies, these consultants have worked as journalists, as members of in-house communication departments, or as public relations practitioners in other agencies. Another asset of these consultants is that their agencies are all founding members of the Turkish PR industry association IDA ${ }^{4}$, which sets the standards of public relations practice in Turkey.

The following table provides information about the relevant experience of Turkish public relations agencies and their founding representatives which are represented in this study:

--- Table 1, around here ---

Students of public relations at graduate level were chosen from one of the leading communication schools (in terms of national university entrance exams results) in İstanbul. However, their undergraduate public relations

\footnotetext{
${ }^{4}$ Representing the companies in Communications Consultancy sector and bringing the leading companies of the sector together, the Communication Consultancies Association of Turkey (IDA) is the Turkey branch of the International Communications Consultancy Organization (ICCO). (http://www.ida.org.tr/eng/)
} 
education varied and thus formed a wider range. As stated above, all active- who is registered and attend classes at the time of research-graduate students were invited to research and graduate student community had a relatively equal size of male and female students and they predominantly worked in public relations related occupations. The student population ranged from newly graduated students to two retired PR professionals. Focus group discussions and auto-ethnographic (Hayano, 1979) methods were particularly employed in students' case but the whole paper in general has ethnographic insights since the authors' have ongoing participatory research projects and also practicing and lecturing responsibilities in public relations industry in Turkey.

\subsection{Research Ethics}

As noted by Potter (1996) the ethical integrity of researchers is an important factor. The researcher should not distort the collected data by overlooking or dismissing contradictions, controversies, or unpredicted data. Building ethical relationships with participants is also necessary. Priority should be given to protecting the identities of the participants through securing the confidentiality of the collected information. The authors followed these ethical considerations. The identities of the public relations professionals and the public relations students were not disclosed. The names of the PR agencies represented by public relations professionals were also not disclosed, in line with the requests of all professionals. Same regulations were applied to students. A basic consent form was provided for all participants.

\subsection{Data Analysis}

In order to determine the significance of digital tools for the public relations professionals and students, to assess the degree of integration of digital communication tools into the public relations practice, to correlate specific digital communication tools with different working areas of public relations, to understand how PR professionals and students assess the credibility of online sources, and to determine the most popular and emerging digital tools and platforms, the authors built on themes and sub-themes. These themes broadly relate to the relationship between the use of digital tools and sources and PR professionals and students in Turkey.

To fulfill this objective, the transcripts of the interviews with public relations professionals, focus group discussions with students were analyzed by examining, comparing and categorizing data. Each interview was reviewed for comments regarding the PR practitioners' and students' perceptions about how the Turkish public relations industry was integrating the digital communication tools and sources with their services. The data was also reviewed to relate specific digital tools with different working areas of public relations. Then, the similarities and differences between the accounts of PR professionals and students were identified to create relevant categories.

The authors placed the accounts of the participants within the context of the global public relations and digital communication literature. Literature in Turkey regarding the relationship of public relations and digital communication tools was also used to provide further context.

\section{Findings}

\section{1- Integrating The Digital Into Public Relations Practice}

The focused research revealed that Turkish public relations practitioners used digital communication tools and platforms in almost all working areas. The reasons listed for using these tools and platforms are, gathering information on various topics relevant to their business; preparing for new business pitches; issues management; crisis management and communication; listening and monitoring the perceptions of different stakeholders; searching for talent; creating content; brand communication; media monitoring; competitive analysis; and 
gathering consumer insights. The fact that the digital is currently being utilized in almost all major working areas of public relations, demonstrates that in the 4 years following Alikilic and Atabek's (2011) assessment of high awareness about existing and future potential of digital tools, the Turkish public relations practitioners are turning their awareness into practice. As noted by a PR practitioner representing Agency c, "Today, it is almost impossible to speak of public relations consultancy services without digital tools. As in all communication practices, digital tools are now seen both by the PR industry and our clients as an integral part of our campaigns and projects".

The reasons for this increasing integration of the digital in public relations practices, according to Turkish public relations practitioners interviewed, is that the digital universe is a significant source of information; hosts a variety of alternative tools and platforms for conveying public relations messages; and provides practitioners insights about stakeholder attitudes and emerging trends. Specifically, the practitioners believe these tools and platforms support them in quickly accessing the latest developments and competitive practices in industries they work for, and the latest news as they unfold. Another important reason cited is that digital tools and platforms enable practitioners to pro-actively take action without delay, such as reaching out to dissatisfied customers or reporting breaking news to their clients.

Besides integrating the digital into their practice, public relations practitioners also reported utilizing various digital platforms for their professional development. The public relations consultants interviewed said they accessed local and international digital public relations sources - such as PR blogs, web sites of PR industry associations, and digital versions of PR industry publications- in order to update themselves on professional issues such as best practices, measurement, evaluation, and talent management.

\section{2- Credibility of Online Sources}

As Sundar (2008:73) contends, assessing the credibility of online sources is a complex phenomenon due to "the multiplicity of sources that are embedded in the numerous layer of dissemination of content". This is confirmed by the responses of Turkish public relations practitioners to the question of how they assess the credibility of online sources they use.

Practitioners believe that not any single online source is credible on its own, and that all online sources need to be cross-checked. This is reflected in the words of a PR practitioner representing Agency a, "The continuous increase in the number of online sources does not mean that they are all reliable. With some exceptions, we always feel the need to double check online content before using it for content support, or before sharing it with our clients".

Criteria used for assessing credibility are reported as relying more on confirmed corporate (or individual) accounts on Facebook and Twitter; verifying news from several alternative sources; and checking information with industry experts. Practitioners also state that, based on their experience, they are able to determine whether an online source is credible or not, because they usually have additional off-line information regarding the source, especially when web sites are concerned. Besides experience, practitioners additionally emphasize the intellectual capacity of the public relations practitioners who are utilizing the online sources. They believe practitioners lacking sufficient background in social, political, and economical issues, and practitioners who are not experienced enough in the practice of public relations are more likely to misjudge the credibility of online sources. The emphasis upon experience and sufficient background in various related issues is reflected through the following comments of two

PR practitioners: "As a long-time experienced consultant with a background in journalism, I can almost always assess whether a certain online source is credible or not. But this is not always the case, especially when younger and less experienced colleagues are concerned" (PR practitioner representing Agency j). 
"My experience and network enable me to correctly diagnose the credibility of an online source, as I can usually relate it to my off-line network. Especially when local sources are concerned, the ownership or the organization behind it would either be my contact, a contact of a colleague, or a name that has come up in professional networks" (PR practitioner representing Agency d).

Underlining the rich variety of opinions expressed online, practitioners say it is usually the case that individuals would consider certain sources, which they believe are close to their point of view, more credible. When this is the case, they would continuously and consistently share information from those sources, neglecting the necessary cross-check. Therefore, it is also important to consider the known political or other affiliations of such individual sources.

Practitioners also agree on the constantly changing character of certain content that is created and presented online, and when this is the case, say they would then consider the related user voting. Examples include the "fresh"/ "trending"/ "hot" alternatives of 9gag, and "Debe" category of Ekşisözlük5 . Other criteria cited for assessing the credibility of online sources are, general public opinion about the source, the ownership of the media outlet, and the sustainable presence of the source. "If the content we are using is from a source that has sustained its existence over a significant period of time, and if there is some sort of general consensus about its trustworthiness, the tendency to rely on that source increases," a PR practitioner representing Agency a said. Students are observed to be more familiar with digital sources in general but less skilled at using them according to industry needs. However, some of them are observed to be even more skilled than many practitioners.

Although students in general are believed to be less skilled in credibility judgements, a few of them can go to lengths of using verification tools such as JPEGsnoof or Exif Viewer in investigating photos or videos. There is a potential that many more tools will be available to use for students in near future. However, students are still at early stages of digital literacy for their own industry. Most of them are skilled at creating content with a clear narrative based on various sources such as university pages, commercial sites (book sites), user generated content sites (from Wikipedia to Ekşisözlük) and news sites. But these bits of collected information were used without a hierarchical categorization of the sources. The narrative seemed factual even if some parts could be controversial to be found in an in depth search. Students, as narrators made them part of a factual whole.

Need for more digital literacy for students is also seen when collecting data about a person who is a relatively well known. Particular promotional sites that give biographical note shape the content creation. An account might particularly be based on one of these sites and more information will be added from other promotional sites. For instance, if the person also lectures, his/her course information will be collected from the institutional site without even paraphrasing. If a person is active in digital traces, his/her accounts seem to determine PR person's output.

Content of major news sites can have over-determination over a PR person's content creation. News sites are particularly useful if a person has made a statement or presented his views. Institutional sites do not give that

\footnotetext{
${ }^{5}$ Ekşisözlük (Sour Dictionary): A collaborative hypertext 'dictionary' based on the concept of Web sites built up on user contribution. The platform is utilized for information sharing on various topics ranging from scientific subjects to everyday life issues, but is also used as a virtual socio-political community to communicate disputed political contents and to share personal views (https://en.wikipedia.org/wiki/Ek\%C5\%9Fi_S\%C3\%B6z|\%C3\%BCk)
} 
kind of information and news sites are used to elaborate on one's biography. However, especially students are less experienced in processing news site originating data and the latter can be included without critical intervention.

\section{3- Online Monitoring: Gathering Information, Creating Content, Managing Issues And Crises}

The new digital technologies have enhanced and speeded up information gathering, utilizing the gathered information for content creation, and tracking and managing both emergent and relevant issues (Porter et al., 2001). It has also been indicated these tools and platforms have become an indispensable part of monitoring and issues management (Alfonso \& Smith, 2008, p. 147), and that the emerging digital technologies present several opportunities for communicators in their efforts to both convey messages on issues of relevance, and to hear the voices of stakeholders affected directly by those issues (Heath, 1998: 274-276). The use of social media for monitoring potential crises, and for depicting misperceptions and concerns of stakeholders has positioned the digital as a significant component of crisis management and communication (Wigley \& Zhang, 2011).

Turkish public relations practitioners interviewed all agree on the weight and significance of Google for information gathering, provided that a sophisticated search with relevant keywords is conducted. Students were seen to be adept in using specific keywords. Some stated that Google search may not give an accurate perspective but offers different viewpoints and it helps to compare different sources. This comparative potential is increased by strategic use of different keywords.

Practitioners indicate that corporate web sites as important sources for accessing information about organizations and brands, and they also report using Wikipedia as a secondary source for such information. As noted by a PR practitioner representing Agency g, "If we are preparing to pitch a potential client, the first place we would look is their web site. Although there is need for caution regarding certain parts of its content, we would usually examine what Wikipedia has to say, if any, for that client".

Some practitioners also cite Google Scholar as a source for especially academic public relations literature. For students, most of the digital source search begins with Googling, too. If a biographical data found in an institutional site, this becomes the starting point. Sometimes this found data is compared to other sources but in most cases institutional data used without much intervention, without much questioning. If a person's own site is available, this becomes the first source, then, other institutional sites follow. The authors observed that institutional information is deemed to be the most credible source. Copy-paste is a common routine here. However, some students pointed out that even institutions may not be trusted and one should be careful. Still this is a minority position. In the meantime, most of the googling do not go after the first 3 pages. Google searching is relatively less relevant when the search is about a breaking news. Social media channels are referred to for more immediate news gathering. Only after following social media channels, Googling occurs to verify, confirm or to find more details.

The major sources reported for monitoring public opinion are the local online dictionaries (Ekşisözlük, Uludağ Sözlük ${ }^{6}$, Inci Sözlük ${ }^{7}$ ). Practitioners think these dictionaries provide them with how different stakeholders with different ideological stances react to various popular or specific issues. In order to monitor the popular

\footnotetext{
${ }^{6}$ Uludağ Sözlük (Uludag Dictionary): a Turkish online social community website similar to Ekşisözlük.

${ }^{7}$ Inci Sözlük (Incı Dictionary): a Turkish online social community website. Even though it has a moderation system for the content, Inci Sozluk lets its users write about almost any content (e.g. pornography, daily life), with some limitations (it excludes politics, third party abuse, religious views, copyright violation etc.). The website represents many some of the many sub-cultures that have grown in Turkey since the 2000s (https://en.wikipedia.org/wiki/\%C4\%B0nci_S\%C3\%B6zl\%C3\%BCk)
} 
conversations, practitioners turn to local platforms such as Listelist ${ }^{8}$ and Onedio $^{9}$. Some students also stated that even before Google search, Ekşisözlük and Uludağ Sözlük were used as a starting point.

Practitioners use several digital platforms for accessing information which would support them in creating content. Examples of such utilization include the use of Ekşisözlük, Slideshare, Wikipedia, and Youtube to support campaign/project presentations, the use of Linkedin for expert articles, the use of 9gag, Reddit and 4chan to access fresh content, and the use of Scoop to enhance creativity.

Marketing communications, like other working areas of public relations, has been significantly impacted by the emergence and establishment of digital communication tools and technologies. The new technologies have expanded and enhanced the uniqueness of marketing communication (or marketing public relations) in engaging consumers in brand communication.

Turkish public relations practitioners, stating that consumers are now content creators as well, report utilizing several tools and platforms in their efforts to support the marketing function. They monitor emerging and competitive marketing communication strategies and tactics through online versions of local and international trade publications such as Marketing Türkiye, Media Cat, PRDaily; and through blogs and vlogs such as digitalbuzzblog. In order to monitor the attitudes of target consumers and to gain consumer insight, they mostly refer to the local online dictionaries. A PR practitioner representing Agency c said; "Ekşisözlük provides us with updated consumer insight. You know, it is not merely a consumer complaint platform. The posts and the related comments could really be enlightening as to stakeholder expectations".

While Instagram and Snapchat are mentioned as platforms for depicting the visual interests of consumers; Facebook and corporate web sites are cited as platforms to assess the rate and nature of brand-consumer interaction. Some practitioners also mention they support the management of closed Facebook groups created specifically for product/service communication.

As for finding out organizational positions on various issues, and depicting the digital communication strategy of organizations, the most preferred online sources are the corporate accounts on Linkedln, Twitter and Facebook. LinkedIn is also referred to as a platform for gathering information about potential employees, as well as expert individuals and organizations which are potential partners for public relations projects. For media monitoring, practitioners mostly use local and international online news portals.

Linkedln network has become a reliable source for students. Students rely on Linkedln profile when an individual is not on the news. Personal biography building is increasingly based on Linkedln as a verifying source in these cases. Only in more critical situations, Linkedln data seems to be questioned and backed by other data sources. However, in the last analysis, this seems to be a better source if the person at stake is a business person. For academics, academia.edu or similar academic networking sites seem to be having a growing impact in personal data collection.

\footnotetext{
${ }^{8}$ Listelist: A new media platform providing content through lists with photographs and sub-titles. (http://listelist.com/hakkimizda/)

${ }^{9}$ Onedio: Launched in 2012 as the first content based social network of Turkey, enabling users to access and to contribute to the most popular news, photographs, galleries and videos; and solving interesting tests. (https://onedio.com/kurumsal/hakkimizda)
} 
Literature notes the use of blogs by public relations practitioners in research and issues management, in order to access expert information and to gain insight into unfamiliar or activist positions (Kent, 2008: 34-35). In line with this, Turkish practitioners think digital tools and platforms are great enablers for tracking emerging issues that are of relevance for their customers, and monitoring their development. In order to track and monitor relevant issues, they mainly refer to expert or activist blogs, activist forums, and Twitter.

Although the incorporation of social media into crisis management and communication by the Turkish public relations practitioners has not been empirically assessed, all practitioners interviewed report making use of digital platforms in anticipating and managing crises. Practitioners say digital platforms are great enablers of early warning, either for reactive preparation or for pro-active intervention in crises; underlining the specific relevance of local online dictionaries, along with Twitter and Facebook. While the monitoring and use of Twitter is dominant during corporate crises, Facebook is utilized more in product/service related crises. Some students stated that after giving priority to trusted institutional accounts, they have focused on Twitter hashtag streams. They have also reported that after investigating a news item, some of the students found keywords to search more in social media accounts. Twitter was particularly resourceful in providing different viewpoints or existing social actors when the issue was about an ongoing event.

In authors' research it became evident that at least two local breaking news sites seem to have dominated this field. Many students and practitioners check out internet Haber and Son Dakika Haber to get the initial information about a breaking news. In later stages, political persuasions determine with sites to follow for more information. State based news agencies are mostly favored by pro-government students. It is also stated that mostly news is seen first in social media sites followed by major news outlets. Here again digital literacy level differs a lot among students. Most are satisfied with the scheme above but some are more adept in comparing and verifying results. Some point out how they focus on Twitter, hashtags through a relatively trusted list of users in information verification. If the news is about two hostile parties, like the downed jet crisis between Turkey and Russia, some students recommended to look at Russian websites, too. This was not a majority position but some believed this could make the information more credible and substantive.

It was interesting to see that few students relied on TV channels or their websites initially. Even those who did, after receiving the initial information, they admitted surfing social media to get more information. In the meantime, when an event like G-20 Summit (See references for the 2015 Summit that took place in Turkey) occurs, information is gathered from relatively stable sources like Wikipedia and mainstream news sites like CNN Türk or Hürriyet. Oppositional views about these events are mostly not included as the information sources do not have them.

Practitioners were more familiar with blogs while students are more focused on social media channels or microblogging. In terms of content creation, curation tools such as Storify or Tweetdeck were used by the latter while the former is not aware of such tools. This follows the trend Kopytoff (2011) mentions, that is younger users do not blog but move to social media.

Finally, the authors did not observe usage of online monitoring tools such as Google Alerts and Mention App. Particularly practitioners rely on professional services that are based on traditional media monitoring. Only a few students stated that they use Tweetdeck and similar tools to monitor social media channels. 


\section{Conclusion}

This study shows use of Internet based technologies are not any more located on "fringe" of public relations. In their work, Coombs and Holladay (2012) demonstrate how activist approaches within PR practitioners rely on Internet but our study shows it has become a routine practice. Jin, Liu and Austin (2011) focus on crisis moments where social media was used by PR professionals. The authors wanted to pursue this adding new fields of inquiry. It is observed that not only in crisis time but much input from digital sources weigh in ongoing ordinary information gatherings. By referring to Wright and Hinson (2009), Jin et al. (2011:76) underline that despite increasing usage "most public relations practitioners do not believe social media are as credible or as accurate as mainstream media". But this seems to have changed since the publication and this paper demonstrates PR practitioners and students are less hesitant to rely on digital sources and this is not limited to crisis times.

In terms of multidirectional communication, this paper confirms a similar situation that Lee and VanDyke (2015) found in their study among US government agencies. Although the digital sources provide multidirectional communication possibilities, PR practitioners or students mostly maintained a passive survey of digital sources instead of interacting with public initiating a dialogic conversation in their inquiries. As a consequence of widespread adoption of new media tools and platforms by both individuals and organizations of all sizes and sorts, public relations practitioners are expected to adopt to these and to integrate them into their practices (Lariscy et al., 2009). The interactive nature of the new media, and the growing influence of a multitude of publics with a rich variety of concerns and interests (Geary, 2005) means that social media communication cannot be left to digital agencies (ilhan, 2012). Future research may focus on more interactive contexts that could not be found in this research.

Sundar (2008) states that overload of information in several different layers needs constant organization but also continual monitoring. Here, Sundar (2008) emphasizes structural characteristics of a website in considering credibility of the information contained. In this paper, initial observations demonstrated that other criteria seem to be more deliberative among students and practitioners than the structural (design related) issues.

The results of the research confirm that practitioners in Turkey, despite with a slow start, have realized the potential of digital communication, and have taken significant steps in both identifying and using the appropriate digital tools and platforms for appropriate public relations practices. Consistent with the reports of their international counterparts (Wright and Hinson, 2009), the responses of Turkish public relations practitioners demonstrate that social media has changed the way they communicate and that it has also enhanced their profession. What is needed in this context is to increase level of digital literacy among students as future PR practitioners and to extend digital usage for the practitioners who are already aware of its significance. However, in the final analysis, the emphasis on social media monitoring, along with the rich variety of monitoring platforms utilized, shows that practitioners are involved in listening to all relevant stakeholders, which is a sign of strategic insight into the evolving practice of public relations. This research demonstrates that a layered penetration of digital tools into public relations practices occur and highlights the fact that contexts should be studied instead of generalized statements about online credibility.

\section{Limitations And Future Research}

Although the findings of this study are practically and theoretically significant, there are certain limitations to be considered. First, the findings regarding Turkish public relations professionals are specific to external communication consultants and cannot be extended to cover in-house corporate communicators. Second, due to the small sample size, the study cannot be generalized to all external communication consultants. However, as the consultants interviewed are presidents of 10 leading PR agencies of Turkey who have witnessed the digital turn in 
Turkish PR industry, their insights are meaningful in understanding how the Turkish PR industry is tackling the digital challenge. Further studies on the topic could be carried out with a larger sample to arrive at more generalizable results regarding the use of online sources in public relations practice. Furthermore, public relations professionals working for in-house corporate communication departments can also be included to understand whether there are significant differences in the attitudes of these two different groups of professionals towards digital sources. Small sample size is also an issue for the findings on student practices. Future research should include a wider size of students from a larger pool of public relations programs. However, sampling can still be defended without broad generalizations as students were involved with a broad range of industries and they were in Istanbul, where is the heart of PR industries in Turkey. Another issue could be the ever-emerging nature of digital tools. Our findings are based on widely used existing tools. Digital economies are rapidly expanding and PR practitioners must be aware of new tools. However, our study still points out the significance of credibility and verification issues and this can be seen as an introductory work for future cases of credibility building.

\section{References}

Alfonso GH and Suzanne S (2008) Crisis communications management on the web: how internet-based technologies are changing the way public relations professionals handle business crises. Journal of Contingencies and Crisis Management 16(3): 143-153.

Alikilic O and Atabek U (2012) Social media adoption among Turkish public relations professionals: A survey of practitioners. Public Relations Review 38(1): 56-63.

Andén-Papadopoulos K and Pantti M (2013) Re-imagining crisis reporting: Professional ideology of journalists and citizen eyewitness images. Journalism, 0(0): 1-18.

Artı PR Official Web Site (2015) Available at, http://www.artipr.com.tr

Avery E, Lariscy R and Sweetser, KD (2010) Social media and shared-or divergent-uses? A co orientation analysis of public relations practitioners and journalists. International Journal of Strategic Communication 4(3): 189-205.

Bersay PR Official Web Site (2015) Available at, http://www.bersay.com.tr

Breakenridge DK (2008) PR 2.0: New media, new tools, new audiences. FT Press.

Canpolat N (2012) Halkla ilişkiler ve reklam ajanslarının hizmet alanları: Web sitelerine yönelik bir inceleme. Niğde Üniversitesi iiBF Dergisi 5(2): 95-106

Chimbel A, Everbach T and Lambiase J (2014) Fuzzy, transparent and fast journalists and public relations practitioners characterize their connections and interactions in social media. The Journal of Social Media in Society 3(1).

Coombs WT and Holladay SJ (2012) Fringe public relations: How activism moves critical PR toward the mainstream. Public Relations Review 38(5): 880-887.

Corner J (2009) Public knowledge and popular culture: spaces and tensions. Media, culture, and society $31(1)$ : 141. 
Denove PR Official Web Site (2015) Available at, http://www.denovepr.com/index.php/blog/

Duhé S (2015) An overview of new media research in public relations journals from 1981 to 2014. Public Relations Review 41(2): 153-169.

Effect PR Official Web Site (2015) Available at, http://www.effect.com.tr/category/blog/

Ekşisözlük (2015) Available at, https://eksisozluk.com/

Geary DL (2005) The decline of media credibility and its impact on public relations. Public Relations Quarterly 50(3): 8 .

Hayano D (1979) Auto-ethnography: Paradigms, problems, and prospects. Human organization 38(1): $99-104$. Hazleton V, Harrison-Rexrode J, Kennan WR and Duhe S (2007). New technologies in the formation of personal and public relations: Social capital and social media. In Duhé S(ed.) New media and public relations. New York, NY: Peter Lang, pp. 91-105.

Heath RL (1998) New communication technologies: An issues management point of view. Public Relations Review 24(3): 273-288.

ICCO - International Communications Consultancy Organization (2016) Available at http://www.iccopr.com/

IDA - Communication Consultancies Association of Turkey (2016) Available at http://www.ida.org.tr/eng/?page id=57

IIhan C (2012) iletişimin yeni normali olarak sosyal medya. Available at, http://kuzguncuk.blogspot.com.tr/2012/03/iletisimin-yeni-normali-olarak-sosyal.html (accessed May 2016).

İlhan C (2014) 2014 yılında iletişime ve PR sektörüne dair 4 öngörü. Available at, http://kuzguncuk.blogspot.com.tr/2014/01/2104-ylnda-iyetisime-ve-pr-sektorune.html (accessed May 2016).

Jin Y, Liu BF, and Austin LL (2011) Examining the role of social media in effective crisis management: The effects of crisis origin, information form, and source on publics' crisis responses. Communication Research, doi: 10.1177/0093650211423918

Kelleher T (2009) Conversational voice, communicated commitment, and public relations outcomes in interactive online communication. Journal of Communication 59(1): 172-188.

Kent ML (2008) Critical analysis of blogging in public relations. Public Relations Review 34(1): 32-40.

Kopytoff VG (2011) Blogs wane as the young drift to sites like Twitter. New York Times 20(11).

Lariscy RW, Avery EJ, Sweetser KD and Howes P (2009) Monitoring public opinion in cyberspace: How corporate public relations is facing the challenge. Public Relations Journal 3(4): 1-17. 
L'Etang J (2013) Public relations: a discipline in transformation. Sociology Compass 7(10): 799-817.

Lee NM and VanDyke MS (2015) Set it and forget it: The one-way use of social media by government agencies communicating science. Science Communication, doi: 1075547015588600.

Listelist Official Web Site (2015) Available at http://listelist.com/

Marketing Türkiye Official Web Site (2015) Available at http://www.marketingturkiye.com.tr/

Marshall C and Rossman GB (2014) Designing qualitative research. SAGE.

Media Cat Official Web Site (2015) Available at, http://www.mediacatonline.com/

Men LR and Tsai WHS (2013) Beyond liking or following: Understanding public engagement on social networking sites in China. Public Relations Review 39(1): 13-22.

MPR PR Official Web Site (2015) Available at, http://www.mpr.com.tr

Onat F (2010) Bir halkla ilişkiler uygulama alanı olarak sosyal medya kullanımı: Sivil toplum örgütleri üzerine bir inceleme. Iletişim: Gazi Üniversitesi Iletişim Fakültesi Kuram ve Araştırma Dergisi 31: 103-121.

Onedio Official Web Site (2015) Available at https://onedio.com/

Öztürk MC and Ayman M (2007) The usage of corporations' web sites for the purpose of public relations. Selçuk iletişim Journal 4: 57-66.

Öztürk MC and Yılmaz RA (2013) Türkiye'de halkla ilişkiler şirketleri ve reklam ajansları web sayfalarını nasıl kullanıyorlar?, Akdeniz Iletisim 19.

Pelenk ÖA and Yılmaz Sert N (2014) Dijital halkla ilişkiler aracı olarak kurumsal bloglar:Türkiye'nin en büyük 500 şirketi üzerine bir araştırma. Global Media Journal: TR Edition, 5(9): 303-321.

Porter L, Sweetser K and Chung D (2009) The blogosphere and public relations: Investigating practitioners' roles and blog use. Journal of Communication Management, 13(3): 250-267.

Porter LV, Sallot LM, Cameron GT, and Shamp S (2001) New technologies and public relations: Exploring practitioners' use of online resources to earn a seat at the management table. Journalism \& Mass Communication Quarterly 78(1): 172-190.

Potter WJ (1996) An analysis of thinking and research about qualitative methods. Psychology Press.

Robinson S and DeShano C (2011) 'Anyone can know': Citizen journalism and the interpretive community of the mainstream press. Journalism, dol: 1464884911415973. 
Robson P and James M (2013). Not everyone's aboard the online public relations train: The use (and non- use) of social media by public relations practitioners. Prism 9(1).

Rubin H and Rubin I (1995) Qualitative interviewing: The art of hearing data. Thousand Oaks, CA: Sage.

Solis B and Breakenridge DK (2009) Putting the public back in public relations: How social media isreinventing the aging business of PR. FT Press.

Sundar, S.S. (2008). The MAIN model: A heuristic approach to understanding technology effects on credibility. Digital media, youth, and credibility, 73-100.

Tekvar SO (2012) Yeni medya ve halkla ilişkilerde dönüşüm: Farklı kurumsal yapılarda halkla ilişkiler algısı ve sosyal paylaşım ağları (Unpublished doctoral dissertation), Ankara Üniversitesi, Sosyal Bilimler Enstitüsü, Halkla ilişkiler ve Tanıtım Anabilim Dalı, Ankara, Türkiye.

Temizel F, Sarıkaya M and Bayram F (2010) Yatırımcı ilişkileri yönetiminde iletişim ve bilgi teknolojilerinin rolü: IMKB 50 endeksi uygulaması. Atatürk Üniversitesi Iktisadi ve Idari Bilimler Dergisi 24(2): 1-20.

Tribeca PR Official Web Site (2015) Available at, http://kuzguncuk.blogspot.com.tr/

Turhan C (2014) Iletişim danışmanlığı sektörü 2010 yılına hızlı girdi. Available at, http://www.cengizturhan.com/2014/05/23/iletisim-danismanligi-sektoru-2010-yilinahizli-girdi/ (accessed March 2016).

Ünite PR Official Web Site (2015), Available at, http://www.unite.com.tr/blog

Verhoeven P, Tench R, Zerfass A, Moreno A and Verčič D (2012) How European PR practitioners handle digital and social media, Public Relations Review 38(1): 162-164.

Wigley S and Zhang W (2011) A study of PR practitioner's use of social media in Crisis planning. Public Relations Journal 5(3): 1-16.

Wright DK and Hinson MD (2009) Examining how public relations practitioners actually are using social media. Public Relations Journal 3(3): 1-33.

Wright DK and Hinson MD (2010) An analysis of new communications media use in public relations: Results of a five-year trend study. Public Relations Journal 4(2): 1-27.

Wright DK and Hinson MD (2013) An updated examination of social and emerging media use in public relations practice: A longitudinal analysis between 2006 and 2013. Public Relations Journal 7(3): 1-39.

Yang A and Kent M (2014) Social media and organizational visibility: A sample of Fortune 500 corporations. Public Relations Review, 40(3), 562-564.

Zarakol PR Official Web Site (2015) Available at, http://www.zarakol.com.tr/ 
Zelizer B (1993) Journalists as interpretive communities. Critical Studies in Media Communication 10(3):

219-

237.

Zerfass A, Verčič D, Verhoeven P, Moreno A and Tench R (2015) European communication monitor 2015 - Creating communication value through listening, messaging, and measurement. Results of a Survey in 41 Countries. Brussels: EACD/EUPRERA, Helios Media.

\section{TABLES}

Table 1: Agencies and their founding presidents represented in this study (compiled from IDA website, 2016)

\begin{tabular}{|l|l|l|l|}
\hline & Date of foundation & $\begin{array}{l}\text { Current number of clients } \\
\text { with annual contracts }\end{array}$ & $\begin{array}{l}\text { Work experience (in years) of } \\
\text { the agency president }\end{array}$ \\
\hline Agency a & 1991 & 28 & 30 \\
\hline Agency b & 1989 & 32 & 32 \\
\hline Agency c & 1997 & 20 & 24 \\
\hline Agency d & 2007 & 27 & 14 \\
\hline Agency e & 1998 & 37 & 23 \\
\hline Agency f & 1992 & 18 & 29 \\
\hline Agency g & 2007 & 39 & 14 \\
\hline Agency h & 1990 & 39 & 27 \\
\hline Agency i & 1995 & 61 & 27 \\
\hline Agency j & 1994 & 58 & 29 \\
\hline
\end{tabular}

